\title{
Physiological quality of bean seeds after application of desiccant herbicides
}

\author{
Cecília Brustolini Rosado ${ }^{1}$ Gustavo Antônio Mendes Pereira ${ }^{1}$ Nayara Pereira Capobiango ${ }^{1 *}$ (D) \\ Renata Pereira Lopes Moreira' ${ }^{1}$ Francisco Cláudio Lopes Freitas ${ }^{1}$ Matheus Ferreira França Teixeira ${ }^{1}$ \\ Antonio Alberto da Silva ${ }^{1}$
}

${ }^{1}$ Universidade Federal de Viçosa (UFV), Viçosa, 36570-900, MG, Brasil. E-mail: nayara.capobiango@hotmail.com. "Corresponding author.

ABSTRACT: The application of desiccant herbicides in the bean crop is fundamental in the production of quality seeds, since it anticipates the harvesting season, which makes it possible to obtain seeds in the period of physiological maturation, when they are reported with maximum accumulation of dry matter, high vigor levels and germination percentage. However, there is little information about the ideal application time of these products to obtain beans of high physiological quality. Therefore, the objective of this study was to evaluate the physiological quality of bean seeds after application of desiccant herbicides at different times in preharvest. The experimental design was a randomized complete block

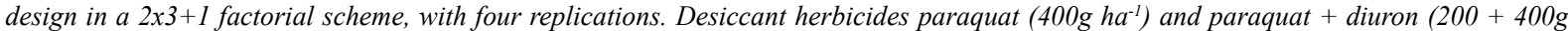
$h a^{-1}$ ) were applied in three phenological stages (R8, R8/R9 and R9), plus one control (without herbicide application). Yield (Kg ha $\left.a^{-1}\right)$, mass of one thousand seeds (g), germination (\%) and seed vigor were evaluated through tests of accelerated aging, electrical conductivity and primary root length. Application of paraquat molecule at the $R 8$ stage and the paraquat + diuron mixture at the $R 8 / R 9$ stage reduced the viability and vigor of the bean seeds, and compromised yield. Applications of the paraquat herbicide at the $R 8 / R 9$ and $R 9$ stages or of the mixture (paraquat + diuron) at the $R 9$ stage preserved the physiological quality of the seeds without; however, affecting yield.

Key words: diuron, paraquat, Phaseolus vulgaris, vigor.

Qualidade fisiológica de sementes de feijão após aplicação de herbicidas dessecantes

RESUMO: A aplicação de herbicidas dessecantes na cultura do feijoeiro é fundamental na produção de sementes de qualidade porque antecipa a época de colheita, o que possibilita a obtenção de sementes no periodo de maturação fisiológica, quando se encontram com máximo acúmulo de matéria seca, elevados niveis de vigor e alta porcentagem de germinação. Todavia, são escassas as informações acerca da época ideal de aplicação desses produtos na obtenção de sementes de feijão de alta qualidade fisiológica. Por essa razão, objetivou-se avaliar a qualidade fisiológica de sementes de feijão após aplicações de herbicidas dessecantes em diferentes épocas na pré-colheita. O delineamento experimental utilizado foi o de blocos casualizados dispostos em esquema fatorial $2 \times 3+1$, com quatro repetições. A aplicação dos herbicidas

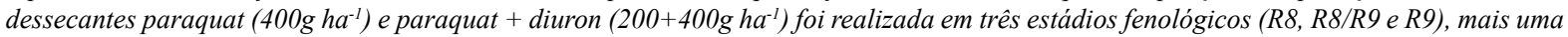
testemunha (sem aplicação do herbicida). Avaliou-se a produtividade ( $\mathrm{Kg} \mathrm{ha}^{-1}$ ), a massa de mil sementes (g), a germinação (\%) e o vigor das sementes por meio dos testes de envelhecimento acelerado, condutividade elétrica e comprimento da raiz primária. A aplicação da molécula de paraquat no estádio $R 8$ e da mistura paraquat + diuron no estágio $R 8 / R 9$ reduziu a viabilidade e o vigor das sementes de feijáo, além disso comprometeu a produtividade. Aplicações dos herbicidas paraquat nos estádios $R 8 / R 9$ e $R 9$ ou da mistura (paraquat + diuron) no estádio R 9 preservaram a qualidade fisiológica das sementes, sem, entretanto, afetar a produtividade.

Palavras-chave: diuron, paraquat, Phaseolus vulgaris, vigor.

\section{INTRODUCTION}

Obtention of quality seeds is one of the most important steps for the productive success of the bean crop. Harvest should be ideally performed shortly after physiological maturity, when the seeds are with the maximum accumulation of dry matter, high vigor levels and high germination percentage (GUIMARÃES et al., 2012). However, at this stage, seed moisture content is high and the morphological structures that still vegetate are conditions that hamper mechanized harvest operations and cause seed damage (PESKE et al., 2012; COELHO et al., 2012). The delay in harvest may reduce germination and seed vigor (SEDYAMA, 2013; FORTI et al., 2013; KEHL et al., 2016; RIGO et al., 2018). Thus, in order to preserve the quality of the harvested product, it is possible to reduce to the maximum the period of 
seed exposure to adverse environmental conditions, mainly oscillations in moisture, temperature, rainfall, attack of pests and diseases (SZARESKI et al., 2016; FOLLMANN et al., 2017).

The application of desiccant at preharvest corresponds to an alternative to reduce the exposure period of physiologically mature seeds to unfavorable environmental conditions, since it allows the anticipation of harvest (LAMEGO et al., 2013). According to the authors, this application, when properly carried out, leads to uniformity in maturation and determination of harvest time, without compromising yield, besides preserving the physical, physiological and sanitary quality of the seeds, even during storage.

However, some important aspects should be considered when using desiccant herbicides, such as the mode of action of the product, the environmental conditions in which it is applied, the phenological stage in which the crop is reported, to avoid possible toxic residues in the harvested material, as it may influence seed production and quality, with reduced germination and vigor, and deterioration during storage (LACERDA, 2005; ZUCHI et al., 2013).

Among the most commonly used desiccant herbicides in beans, paraquat stands out, due to its efficiency of action (GUIMARÃES et al., 2012; KAPPES et al., 2012), once it is a contact herbicide that inhibits photosystem I, causing toxicity and death of the plant tissue soon after its application (EKMEKCI \& TERZIOGLU, 2005 ), and the translocation of the product into the seeds is limited.

Herbicides that have a higher translocation than those of contact may cause additional seed damage, such as the desiccation of common beans with Gramocil ${ }^{\circledR}$, a mixture of paraquat + diuron, where diuron belongs to the group of photosystem II inhibitor herbicides, which leads to a reduction in electron transport to photosystem I, reducing the speed of action of paraquat (NORSWORTHY et al., 2011). According to the authors, reduction in the speed of action of this herbicide allows greater diffusion of the molecule in the plant tissues and, as a consequence, it can reach the seeds with greater ease.

Therefore, due to the scarcity of information on the ideal moment of application of the products paraquat and the mixture paraquat + diuron in the bean crop to obtain quality seeds, the objective of this study were to evaluate the physiological quality of bean seeds after application of desiccant herbicides at different times in preharvest.

\section{MATERIALS AND METHODS}

The study was conducted in a randomized block design in the $2 \times 3+1$ factorial scheme with four replicates, two herbicides (paraquat $400 \mathrm{~g}$ $\mathrm{ha}^{-1}$ and paraquat + diuron $200+400 \mathrm{~g} \mathrm{ha}^{-1}$ ), three desiccation times, at different phenological stages: R8 (before physiological maturation, $50 \%$ of the total beans beginning to show reddish color); R8/ R9 (at physiological maturation, 90\% of the total beans showed reddish color); R9 (after physiological maturation, $50 \%$ of the beans were brown) and one control (without application of the herbicide).

Each experimental plot consisted of three lines with $6 \mathrm{~m}$ length, spaced at $0.5 \mathrm{~m}$, and the useful part consisted of the central line, discounting $0.5 \mathrm{~m}$ at each end. The climatic data regarding rainfall and maximum and minimum daily temperatures during the experiment period are shown in figure 1. 'The Ouro Vermelho' bean sowing was carried out on April 6,2015 , with a density of 12.5 seeds per linear meter, using a mechanical seeder prepared for no-tilling. Simultaneously to sowing, $300 \mathrm{~kg} \mathrm{ha}^{-1}$ of fertilizer 8-28-16 (N-P-K) was applied to the planting line and, according to the need, additional irrigations were carried out by spraying and manual weeding (two), in order to avoid weed competition.

The application of herbicides Gramoxone ${ }^{\circledR}$ (paraquat) and Gramocil $^{\circledR}$ (diuron + paraquat) was performed using a costal sprayer. The sprayer was equipped with bar containing three XR11003 tips, spaced at $0.50 \mathrm{~m}$ and, during the application, a constant pressure of $300 \mathrm{kPa}$ was maintained by pressurized $\mathrm{CO}_{2}$. The nozzle volume was equivalent to $250 \mathrm{~L} \mathrm{ha}^{-1}$ and the application was carried out in the afternoon, recording a mean temperature of $21.1^{\circ} \mathrm{C}$, relative humidity of $65 \%$ and wind speed of $1.4 \mathrm{~m} / \mathrm{s}$; application dates are shown in figure 1 .

Harvesting was performed manually when the plants were defoliated, with dry beans and seed water content around 20\%. After harvest, a seed sample was collected for the evaluation of the physiological quality by germination, accelerated aging, cold and electrical conductivity tests, according to the methodology proposed by KRZYZANOWSKI (1999).

\section{Germination}

Germination test was carried out using 50 bean seeds per replicate, which were sowed on three germitest $^{\circledR}$ paper sheets, previously moistened with distilled water at a proportion of 2.5 times the weight of the paper. $r$ Rolls were kept in a germinator at a 


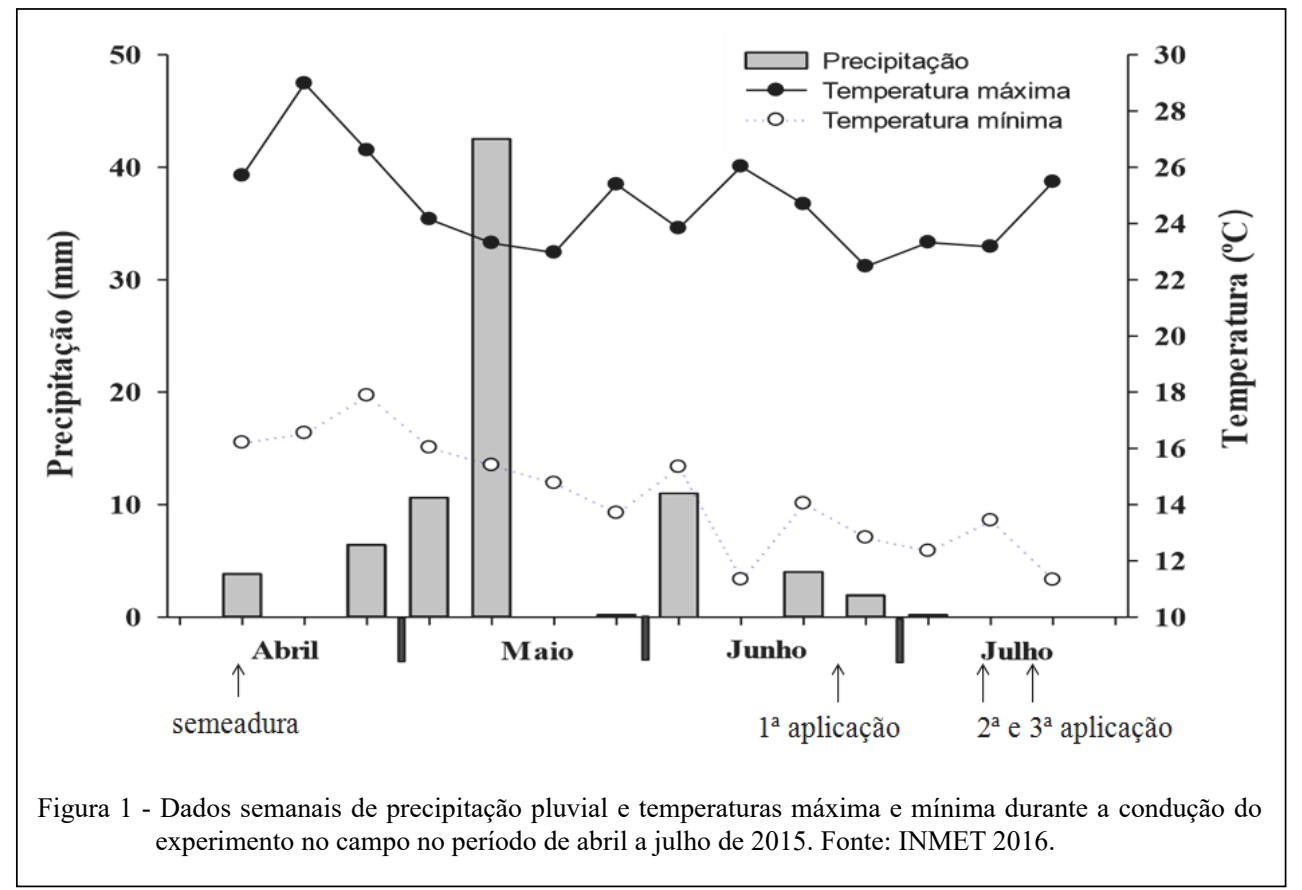

temperature of $25 \pm 2{ }^{\circ} \mathrm{C}$. In order to obtain results, counts were performed at five and nine days, the seedlings were classified as normal or abnormal, and results were expressed as percentage of normal seedlings, after obtaining the arithmetic mean of the replicates (BRASIL, 2009).

\section{First germination count (FGC)}

It was carried out in conjunction with the germination test, in which the number of normal seedlings was evaluated on the fifth day after sowing. Results were expressed as percentage of normal seedlings (BRASIL, 2009).

\section{Primary root size}

At the first germination count, 10 normal seedlings of each replicate were randomly collected, and the primary root length of the seedlings was measured using a ruler; the result was expressed in centimeters.

\section{Accelerated aging}

It was carried out using the acrylic box with lid $(11 \times 11 \times 3.5 \mathrm{~cm})$ method, placing 200 seeds in a single layeron the hanging screen inside the box, containing $40 \mathrm{~mL}$ of water. They were closed and maintained at $42{ }^{\circ} \mathrm{C}$ with $100 \%$ air relative humidity for 72 hours (KRZYZANOWSKI et al., 1999), until the water content of the seeds reached values around $22 \%$ wet basis, which was estimated by the greenhouse method at $105 \pm 3{ }^{\circ} \mathrm{C}$ (BRASIL, 2009) for 24 hours. After this period, the seeds were submitted to the germination test and, on the fifth day after installation, the percentage of normal seedlings was determined.

\section{Electric conductivity}

It was performed according to the methodology recommended by VIEIRA \& KRZYZANOWSKI (1999), in which 50 seeds per replicate were previously weighed, placed in plastic cups containing $25 \mathrm{~mL}$ of deionized water and kept at $25^{\circ} \mathrm{C}$ for 24 hours. Subsequently, the electrical conductivity was measured using a conductivity meter (Digimed ${ }^{\mathbb{B}}$ DM32), whose values were expressed in $\mu \mathrm{S} \mathrm{cm}^{-1} \mathrm{~g}^{-1}$.

\section{Agronomic characteristics}

Mass of 1,000 seeds

It was estimated by weighing eight samples of 100 seeds, the mean values were calculated and multiplied by 10 to make the correction of the mass to 1000 seeds, with the results expressed in grams (BRASIL, 2009).

\section{Yield}

It was estimated by weighing the seeds harvested from the useful area of each replicate,

Ciência Rural, v.49, n.9, 2019. 
after determination of moisture by the greenhouse method at $105 \pm 3{ }^{\circ} \mathrm{C}$ (BRASIL, 2009), correcting the data to $13 \%$ moisture, according to Equation, Yield $=\frac{\text { weight } x(100-\text { moisture })}{87}$ with yield expressed in kg ha-1.

\section{Number of days of harvest anticipation}

It was determined by the difference, in days, of the date of harvest of the desiccation treatments in relation to the control harvest. The results were submitted to analysis of variance and, when the interaction between application time and herbicides was significant $(\mathrm{P}<0.05)$, the necessary measurements were performed. The Tukey test was used to verify the behavior of the application time of the desiccants, within each applied herbicide, as well as the behavior of each herbicide within each application time. To compare the treatments with the control, the Dunnet test was applied at 5\% probability.

\section{RESULTS AND DISCUSSION}

Seed germination was influenced only by the application times of the desiccants (Table 1), being reduced when the herbicides were applied at the R8 stage, compared to the bean R9 stage. The paraquat applied at $\mathrm{R} 8$ reduced the value of this variable in comparison to the absence of herbicide application. DOMINGOS et al. (1997) and PINTO et al. (2014) observed that the desiccation time did not affect the seed germination of black and carioca beans, respectively.

The lower seed germination results may have been due to the first season evaluated in this study (R8, 24 days after flowering (DAF)), when compared to PINTO et al. (2014), 39 DAF and DOMINGOS et al. (1997), 26 DAF. The reduction in germination at the R8 stage may be due to the rapid inhibition of photosynthesis caused by paraquat, which resulted in lower transport of photoassimilates to the seeds (PEREIRA et al., 2015).

For the germination at the first count, there was a significant interaction between application time and herbicide factors (Table 1), and the application of paraquat at the R8 stage reduced the value of this variable in comparison with the other seasons, whereas for the mixture (paraquat + diuron), higher ratios were observed at the $\mathrm{R} 9$ stage. When comparing the herbicides within each application time, higher rates were observed when the mixture was applied in relation to paraquat isolated at stages $\mathrm{R} 8$ and $\mathrm{R} 9$. Also for the first count, paraquat applied at the R8 stage reduced the percentage of germinated seeds at the first count, compared to the control.
Therefore, it can be inferred that there was a reduction in seed vigor, since the first germination count indirectly evaluates the germination speed (KRZYZANOWSKI et al., 1999), which was also verified by KAPPES et al. (2012), when evaluating the influence of the desiccation time with the herbicide paraquat on this variable in bean seeds.

There was no interaction between the factors in the primary root size; thus, the influence of the isolated factors was studied (Table 1). It was verified that the application of the desiccants at the R8 stage reduced root size. The application of the isolated paraquat resulted in larger primary root sizes than the application of the mixture, whereas the use of paraquat at the R8/R9 and R9 stages yielded an increase in this variable in relation to the control. Increased root growth is an indicative of seedlings with greater capacity for transformation and storage of reserve supplies in tissues, besides greater incorporation by the embryonic axis (KRZYZANOWSKI et al., 1999).

For the accelerated aging test (Table 1), there was a significant interaction between herbicides and application times, with higher germination at the R8/R9 stage, followed by $\mathrm{R} 9$ and $\mathrm{R} 8$, when paraquat was applied and, in the use of the mixture, the highest germination was obtained at the R9 stage. When comparing the herbicides at each application time, it was verified that higher vigor levels were obtained when the herbicide mixture was applied in relation to the isolated product at stages R8 and R9, and without effects for the R8/R9 stage. However, when evaluated by the accelerated aging test, greater reductions in vigor were observed for the application of paraquat at stage $\mathrm{R} 8$, whose values were lower than those observed in the control, which was similar to the other treatments.

For electrical conductivity, there was also a significant interaction between the factors (Table 1), and the lowest levels of this variable were observed at R8 and R9 stages, where paraquat was applied, while the paraquat + diuron mixture at $\mathrm{R} 8 / \mathrm{R} 9$ provided lower electrical conductivity and, in the comparison between herbicides, better results were observed with the use of the mixture at stages R8 and R9.

When the seeds of the control treatment were compared at the $\mathrm{R} 8$ stage for the application of paraquat and R8/R9 for the mixture, lower values were obtained, indicating a higher integrity of the cell membranes. The electrical conductivity test is inversely proportional to the values obtained; the higher the conductivity value, the lower the cell membrane structuring, reducing seed physiological quality.

In the study developed by COELHO et al. (2012), the electrical conductivity of bean seeds 
Table 1 - Germination, first germination count, accelerated aging, root size and electric conductivity of bean seeds submitted to pre-harvest desiccation at different times.

\begin{tabular}{|c|c|c|c|c|}
\hline \multirow[t]{2}{*}{ Evaluation } & \multirow[t]{2}{*}{ Desiccation time } & \multicolumn{2}{|c|}{ 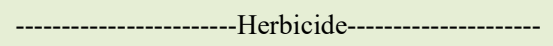 } & \multirow[t]{2}{*}{ Mean } \\
\hline & & Paraquat & Paraquat + Diuron & \\
\hline 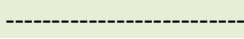 & & --------\%"--------- & 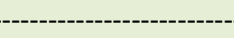 & -------. \\
\hline \multirow{6}{*}{ Germination } & R8 & $93^{*}$ & 97 & $95 \mathrm{~b}$ \\
\hline & R8/R9 & 98 & 97 & $98 \mathrm{ab}$ \\
\hline & R9 & 98 & 98 & $98 \mathrm{a}$ \\
\hline & Mean & 96.33 & 97.33 & \\
\hline & Control & ----------------------. & -------------------------- & \\
\hline & $\mathrm{CV}(\%)$ & ---------------------- & -------------------------- & \\
\hline \multirow{6}{*}{ First count } & R8 & $66 b B^{*}$ & $84 \mathrm{bA}$ & 75 \\
\hline & R8/R9 & $86 \mathrm{aA}$ & $81 \mathrm{bA}$ & 84 \\
\hline & R9 & $84 \mathrm{aB}$ & $92 \mathrm{aA}$ & 88 \\
\hline & Mean & 78.67 & 85.67 & \\
\hline & Control & ------------------- & 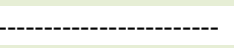 & \\
\hline & $\mathrm{CV}(\%)$ & -------------------- & 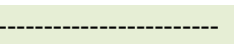 & \\
\hline \multirow{6}{*}{ Accelerated aging } & $\mathrm{R} 8$ & $81 \mathrm{cB}^{*}$ & $94 \mathrm{bA}$ & 87 \\
\hline & R8/R9 & $97 \mathrm{aA}$ & $92 \mathrm{bA}$ & 94 \\
\hline & R9 & $90 \mathrm{bB}$ & $99 \mathrm{aA}$ & 94 \\
\hline & Mean & 89.33 & 95.0 & \\
\hline & Control & ----------------------- & -------------------------- & \\
\hline & $\mathrm{CV}(\%)$ & 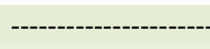 & 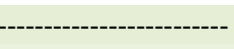 & \\
\hline --------------------- & ---------------. & ---------cm------' & - & --------- \\
\hline \multirow{6}{*}{ Root size } & $\mathrm{R} 8$ & 5.48 & 5.28 & $5.35 \mathrm{~b}$ \\
\hline & $\mathrm{R} 8 / \mathrm{R} 9$ & $6.98^{*}$ & 6.08 & $6.53 \mathrm{a}$ \\
\hline & R9 & $7.98^{*}$ & 6.35 & $7.16 \mathrm{a}$ \\
\hline & Mean & $6.81 \mathrm{~A}$ & $5.90 \mathrm{~B}$ & \\
\hline & Control & --------------------. & ------------------------' & \\
\hline & $\mathrm{CV}(\%)$ & 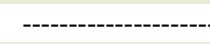 & |----------------------- & \\
\hline \multirow{7}{*}{ Electric conductivity } & -------------------- & $\mu \mathrm{Scm}^{-1} \mathrm{~g}^{-1}$ & -------------------------- & -------. \\
\hline & R8 & $63.46 \mathrm{bB}^{*}$ & $73.88 \mathrm{aA}$ & 68.67 \\
\hline & R8/R9 & $76.78 \mathrm{aA}$ & $58.84 \mathrm{bA}^{*}$ & 67.81 \\
\hline & R9 & $65.36 \mathrm{bB}$ & $75.40 \mathrm{aA}$ & 70.38 \\
\hline & Mean & 68.53 & 69.38 & \\
\hline & Control & 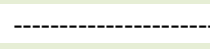 & ------------------------- & \\
\hline & $\mathrm{CV}(\%)$ & ---------------------- & --------------------------- & \\
\hline
\end{tabular}

Within the same variable, means followed by the same letter, lowercase in the column and uppercase in the row, do not differ statistically by the Tukey test at $5 \%$ probability.

*different from the control by the Dunnett test at $5 \%$ probability.

ranged from 41.24 to $89.73 \mu \mathrm{S} \mathrm{cm}^{-1} \mathrm{~g}^{-1}$ and, in the study of KAPPES et al. (2012), it ranged from 57.10 to $72.10 \mu \mathrm{S} \mathrm{cm}^{-1} \mathrm{~g}^{-1}$; these values are similar to those obtained in this study. However, there are differences in these values, once the value of the electrical conductivity varies according to the amount and type of compounds present in the leachate solution (KRZYZANOWSKI et al., 1999), and can thus vary its value for each species. In the studies of COELHO et al. (2012) and KAPPES et al. (2012), it was also determined that the desiccation of some treatments preserved the integrity of the cell membranes without affecting the yield or the quality of bean seeds.

For the mass of 1000 seeds, whose interaction between the factors herbicide and application time was also significant (Table 2), it was observed that the application of paraquat at the $\mathrm{R} 8$ stage and the mixture at the R8 / R9 stage reduced the values of this variable. Better results were achieved when the mixture was applied, compared to the

Ciência Rural, v.49, n.9, 2019. 
Table 2 - Mass of 1000 seeds and yield $\left(\mathrm{kg} \mathrm{ha}^{-1}\right)$ of beans as a function of desiccation time and herbicide.

\begin{tabular}{|c|c|c|c|c|}
\hline \multirow[t]{2}{*}{ Evaluation } & \multirow[t]{2}{*}{ Desiccation time } & \multicolumn{2}{|c|}{ 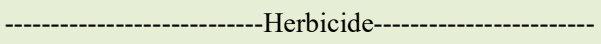 } & \multirow[t]{2}{*}{ Mean } \\
\hline & & Paraquat & Paraquat + Diuron & \\
\hline \multirow{6}{*}{ Mass of 1000 seeds } & R8 & $14511 \mathrm{cB}^{*}$ & $18125 \mathrm{a}$ & 16318 \\
\hline & R8/R9 & $145.11 \mathrm{cB}$ & $15122 \mathrm{bB}^{*}$ & 17168 \\
\hline & R9 & $178.93 \mathrm{bA}$ & $183.97 \mathrm{aA}$ & 181.45 \\
\hline & Mean & 172.05 & 172.15 & \\
\hline & Control & 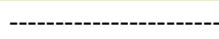 & 26------------------------ & \\
\hline & $\mathrm{CV}(\%)$ & 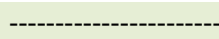 & 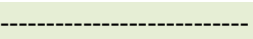 & \\
\hline \multirow{6}{*}{ Yield } & R8 & $2,259.17 \mathrm{bA}$ & $2,417.23 \mathrm{abA}$ & $2,338.20$ \\
\hline & R8/R9 & $3,084.75 \mathrm{aA}$ & $2,301.90 \mathrm{bB}$ & $2,693.32$ \\
\hline & R9 & $2,735.66 \mathrm{abA}$ & $2,925.43 \mathrm{aA}$ & $2,830.55$ \\
\hline & Mean & $2,693.19$ & $2,548.18$ & \\
\hline & Control & ---------------------- & |0------------------------ & \\
\hline & CV $(\%)$ & ------------------------ & |-------------------------- & \\
\hline
\end{tabular}

Means followed by the same letter, lowercase in the column and uppercase in the row, do not differ statistically by the Tukey test at $5 \%$ probability.

"different from the control by the Dunnett test at $5 \%$ probability.

product isolated at the R8 stage; however, at the R9 stage, the applications did not cause differences in the mass of 1000 seeds. The paraquat applied at the $\mathrm{R} 8$ stage and the mixture supplied at $\mathrm{R} 8 / \mathrm{R} 9$ reduced mass accumulation in the seeds relative to the control, without herbicide application.

Between herbicides and application times on yield (Table 2), there was a significant interaction, in which the application of paraquat at the R8 stage reduced yield, compared to the other times. In the mixture (paraquat + diuron), yield was reduced when they were applied at the R8/R9 stage, compared to the R9 stage. In the comparison between herbicides within each time, differences in yield were only reported when the herbicides were applied at the R8/ R9 stage, with better results for the isolated use of paraquat. Treatments did not differ from the control in any of the combinations evaluated, although a numerical difference was noticed, with lower values for the R8 stage for the two desiccants, and in R9 for paraquat + diuron.

Plants desiccated prior to physiological maturation (R8) may interrupt seed growth by ceasing the flow of photoassimilates produced in the photosynthetic apparatus and stored in seed storage tissues; therefore, affecting yield. KAPPES et al. (2012) reported that desiccation performed at early times, 30 days after flowering, decreased yield.
With the application of desiccant herbicides, it was possible to anticipate the bean seed harvesting at 11,8 and 6 days in relation to the control, with respect to stages R8, R8/R9 and R9, respectively. Harvest anticipation allows, within a short period of time, the provision of the area for the implantation of another crop, besides the reduction in the exposure time of the seeds to bad weather in the field, contributing to the preservation of the physiological integrity of the harvested product. It is noteworthy that, even with the seed quality losses observed by the application of desiccants at stage $\mathrm{R} 8$ to anticipate harvest, this can be favorable in order to avoid total seed loss in the field under unfavorable climatic conditions, such as the occurrence of rainfall for extended time periods.

\section{CONCLUSION}

Applications of paraquat at the R8/R9 and R9 stages or of the mixture (paraquat + diuron) at the R9 stage preserve the physiological quality of the seeds and do not affect yield.

\section{ACKNOWLEDGEMENTS}

The authors would like to thank the Universidade Federal de Viçosa, and Conselho Nacional de Desenvolvimento Cientítico e Tecnológico $(\mathrm{CNPq})$, and was financed in part by the 
Coordenação de Aperfeiçoamento de Pessoal de Nível Superior (CAPES), Brasil - Finance code 001.

\section{DECLARATION OF CONFLICT OF INTERESTS}

The authors declare no conflict of interest. The founding sponsors had no role in the design of the study; in the collection, analyses, or interpretation of data; in the writing of the manuscript, and in the decision to publish the results.

\section{AUTHORS' CONTRIBUTIONS}

The authors contributed equally to the manuscript.

\section{REFERENCES}

BRASIL. Ministério da Agricultura, Pecuária e Abastecimento. Regras para análise de sementes. Ministério da Agricultura, Pecuária e Abastecimento. Secretaria de Defesa Agropecuária. Brasília: MAPA/ACS, 2009.395p.

COELHO, C. M. M.; et al. The effect of pre-harvest desiccation on the yield and physiological quality of landrace bean seeds. Ciências Agrárias, v.3, n.1, p.2973-2980, 2012. Available from: <file://C:/ Users/ACER/Downloads/8001-55801-1-PB.pdf>. Accessed: Mar. 16, 2018. doi: 10.5433/1679-0359.2012v33Supl1p2973.

DOMINGOS, P.; et al. Bean seed quality affected by desiccants, in four stages of application. Revista Brasileira de Sementes, v.19, n.2, p.275-282, 1997. Available from: <http://dx.doi. org/10.17801/0101-3122/rbs.v19n2p275-282>. Accessed: Mar. 16, 2018. doi: 10.17801/0101-3122/rbs.v19n2p275-282.

EKMEKCI, Y.; TERZIOGLU, S. Effects of oxidative stress induced by paraquat on wild and cultivated wheats. Pesticide Biochemistry and Pysiology, v.83, n.2, p.69-81, 2005. Available from: <https:// www.sciencedirect.com/science/article/pii/S0048357505000507>. Accessed: Mar. 16, 2018. doi: 10.1016/j.pestbp.2005.03.012.

FOLLMANN, D. N.; et al. Relações lineares entre caracteres de soja safrinha. Revista de Ciências Agrárias, v.40, n.1, p.213-221, 2017. Available from: <https://doi.org/10.19084/RCA16027>. Accessed: Mar. 16, 2018.

FORTI, V. A.; et al. Weathering damage in soybean seeds: assessment, seed anatomy and seed physiological potential. Seed Technology, v.35 n.2, p.213-224, 2013. Available from: <http:// www.jstor.org/stable/24642271>. Accessed: Mar. 16, 2018.

GUIMARÃES, V. F.; et al. Produtividade e qualidade de sementes de soja em função de estágios de dessecação e herbicidas. Planta Daninha, v.30, n.3, p.567-573, 2012. Available from: <http:// dx.doi.org/10.1590/S0100-83582012000300012>. Accessed: Mar. 16, 2018. doi: 10.1590/S0100-83582012000300012.

KAPPES, C.; et al. Qualidade fisiológica de sementes e crescimento de plântulas de feijoeiro, em função de aplicações de paraquat em pré-colheita. Pesquisa Agropecuária Tropical, v.42, n.1, p.9-18, 2012. Available from: <http://dx.doi.org/10.1590/S1983-
40632012000100002>. Accessed: Mar. 16, 2018. doi: 10.1590/ S1983- 40632012000100002.

KEHL, K.; et al. Plant pre harvest desiccation and phisiological performance of wheat seeds before and after storage. International Journal of Current Research, v.8, n.9, p.38456-38460, 2016. Available from: <http://www.journalcra.com/article/plant-preharvest-desiccation-and-physiological-performance-wheat-seedsand-after-storage>. Accessed: Mar. 16, 2018.

KRZYZANOWSKI, F. C.; et al. Vigor de sementes: conceitos e testes. Londrina. ABRATES, 1999. p. 1-24.

LACERDA, A. L. S.; et al. Efeitos da dessecação de plantas de soja no potencial fisiológico e sanitário das sementes. Bragantia, v.64, n.3, p.447-457, 2005.

LAMEGO, F. P.; et al. Dessecação pré colheita e efeitos sobre a produtividade e qualidade fisiológica de sementes. Planta Daninha, v.31, n.1, p.929-938, 2013. Available from: $<$ https://doi.org/10.1590/ S0100-83582013000400019>. Accessed: Mar. 16, 2018.

NORSWORTHY, J. K.; et al. Evaluation of combinations of paraquat plus photosystem II - inhibiting herbicides for controlling failed stands of maize (Zea mays). Crop Protection, v.30, n.3, p.307-310, 2011. Available from: <https://doi.org/10.1016/j.cropro.2010.11.016>. Accessed: Mar. 16, 2018. doi: 10.1016/j.cropro.2010.11.016.

PEREIRA, T.; et al. Dessecação química para antecipação de colheita em cultivares de soja. Ciências Agrárias, v.36, n.4, p.2383-2394, 2015. Available from: <http://www.uel.br/revistas/ uel/index.php/semagrarias/article/viewFile/16028/16779>. Accessed: Mar. 16, 2018. doi: 10.5433/1679-0359.

PESKE, S. T.; et al. Sementes: fundamentos científicos e tecnológicos (3rd ed., p. 573). Pelotas, Brasil, 2012.

PINTO, M. A. B.; et al. Productivity and pysiological quality of seeds wit burn down herbicides at the pre harvest of bean crops. Journal of Seed Science, v.6, n.4, p.384-391, 2014. Available from: <http://dx.doi.org/10.1590/2317-1545v36n4997>. Accessed: Mar. 16, 2018. doi: 10.1590/2317-1545v36n4997.

RIGO, G. A.; et al. Micronutrient content and physiological quality of soybean seeds. Journal of Agricultural Science, v.10, n.4, p.223-230, 2018. Available from: <https://doi.org/10.5539/jas. v10n4p223>. Accessed: Mar. 16, 2019.

SEDYAMA, T. Tecnologia e produção de sementes de soja. Londrina. 2013. p. 352.

SZARESKI, V. J.; et al. Pre-harvest desiccation and seed production in soybean crops. International Journal of Current Research, v.8, n.11, p.41534-41537, 2016. Available from: <http://www.journalcra.com/ sites/default/files/issue-pdf/18108.pdf>. Accessed: Mar. 16, 2018.

VIEIRA, R. D.; KRZYZANOWSKI, F. C. Teste de condutividade elétrica. In: KRZYZANOWSKI, F. C.; et al. (Eds.). Vigor de sementes: conceitos e testes. Londrina: ABRATES, 1999. p.1-26.

ZUCHI, J.; et al. Physiological quality of dynamically cooled and stored soybean seeds. Journal of Seed Science, v.35, n.3, p.353360, 2013. Accessed: Mar. 16, 2018. 